\title{
Value-added and Supporting - Inhibiting Factors for The Wet Processing of Coffee
}

\author{
Yuli Hariyati \\ Agribusiness Study Program, Agricultural Faculty, Jember University, East Java, Indonesia \\ E-mail: yulihariyati@ymail.com
}

\begin{abstract}
Coffee is one of the annual crops which are widely favored by coffee enjoyers. SidomulyoVillage is one of the fourth largest coffee producing villages in District of Silo with a land area of 180 ha in 2009 . Coffee experiences a process of harvest and post harvest; one of the activities of post-harvest is coffee processing. Coffee processing is divided into two; wet processing and dry processing. The majority of farmers in SidomulyoVillage do dry processing; about $75 \%$ of farmers do dry processing and $25 \%$ of farmers do wet processing. This research was intended to: (1) to find out the value added coffee processed,(2) to identify supporting and inhibiting factors the farmers to do wet processing, and (3) to identify the income differences of farmers undertakingthe wet and dry processing. This research was carried out on purpose (purposive method) in the Sidomulyo Village, District of Silo, by taking samples; that is the total sampling of farmer group of Sidomulyo 1. Data analysis used including value added, Force Field and financial analysis. The research results showed that: (1) ) value added of coffee beans processing turn to HS coffee was IDR 975,whereas coffee beans processing turn to ose coffee was IDR 529,-. (2) The strongest supporting factor of wet processing was the ability to absorb workers, while the strongest inhibiting factor of wet processing was less adequate water facilities; (3) The coffee farmer incomescarrying out wet processing and dry processing were different. PerHa coffee income of wet processing was IDR 11,228,805,and that of dry processing per ha was IDR 7,901,249.
\end{abstract}

Keywords - value added, supporting and inhibiting, farmers income, coffee

\section{INTRODUCTION}

Coffee (Coffea spp. L.) is one of strategic plantation comodities. Robusta coffee product managed by public and public plantation in Jember achieved 1.798,695 ton. The coffee public plantation is spread out to some sub-districts, especially in Kalisat and Silo. Sidomulyo is one of the villages in Silo sub-district that produces Robusta coffee commodity. Coffee experiences a process of harvest and postharvest; one of the activities of post-harvest is coffee processing. Coffee processing is divided into two; wet processing and dry processing. The majority of farmers in Sidomulyo Village do dry processing; about $75 \%$ of farmers do dry processing and $25 \%$ of farmers do wet processing. By the unstable coffee selling price by the farmers causes they worry to run their business, so that coffee public plantation farmers in Sidomulyo village need to calculate of the price and income profit. That's why, farmers need a guide line to choose processing method that owns the highest value added, farmer's income and identify supporting and inhibiting factors the farmers to do wet processing to recommended the further policy in developing of coffee processed products.

\section{METHOD}

Sampling method in this research is using purposive cluster sampling. Cluster method is shown with the chosen farmer groups Sidomulyo I of 4 other farmer groups (farmer groups Suluh Tani, Curah Manis I, Barokah and Tunas Jaya). All members of farmer groups Sidomulyo 1 as sample, data analysis methods used include the formulation of Added

Value (Value added) are as follows:

$\mathrm{VA}=\mathrm{NP}-\mathrm{IC}$

Description:

VA: Value Added or value added in processed products ( $\mathrm{Rp} / \mathrm{kg}$ of feedstock).

NP: Production value is sales of production ( $\mathrm{Rp} / \mathrm{kg}$ of feedstock). IC: Intermediate Cost is support costs in the production process in addition to labor costs $(\mathrm{Rp} / \mathrm{kg}$ of feedstock)

Criteria Decision Making:

a. VA $>0$, coffee processing stages can provide added value

b. VA $\leq 0$, coffee processing stages have not been able to provide value-added 
To test for the driving factors and inhibiting farmers in conducting the wet processing of coffee, used force field analysis or Force Field Analysis (FFA). The calculation coffee farm income:

$$
\begin{array}{ll}
\pi & =\mathrm{TR}-\mathrm{TC} \\
\mathrm{TR} & =(\mathrm{P} \times \mathrm{Q}) \\
\mathrm{TC} & =(\mathrm{VC}+\mathrm{FC})
\end{array}
$$

Description:

$$
\begin{array}{ll}
\pi & =\text { Net income or profit }(\mathrm{Rp}) \\
\mathrm{TR} & =\text { total revenue }(\mathrm{Rp}) \\
\mathrm{TC} & =\text { total cost }(\mathrm{Rp}) \\
\mathrm{P} & =\text { Price the output } \\
\mathrm{Q} & =\text { Production obtained in a farm } \\
\mathrm{FC} & =\text { fix cost }(\mathrm{Rp}) \\
\mathrm{VC} & =\text { variable costs }(\mathrm{Rp})
\end{array}
$$

To find out the hypotheses about the difference between incomes of farmers do wet processing by farmers to dry processing which uses different test or $\mathrm{t}$ distribution ( $\mathrm{t}$ student) with the formulation of the following formula (Hasan, 1999).

\section{RESULT AND DISCUSSION}

\section{A. Value Added Processing Ose Coffee or HS}

In the processing of gelondong coffee became dry ose coffee, farmers processing services charged Rp 20.00 per kilogram. That was because farmers did not have the tools to process the gelondong coffee into ose coffee. Therefore,the farmers brought coffee logs for processing services charge. Processing services usually approached the farmer who will cultivate, so that the coffee farmers who want to process logs into contact ose processing services first. In the processing of logs if dry coffee into coffee processing loop to dry though, there is a shrinkage of about 0.7 to 0.8 .

Analysis of value added in the processing of gelondong coffee into ose coffee (dry method) and into Horn Skin coffee / HS (wet method) are presented in the Table 1.

TABLE I

VAlue AdDEd Processing GelONDONG COFFEE BeING OSE COFFEE OR HS (KG)

\begin{tabular}{|c|l|c|c|}
\hline No & \multicolumn{1}{|c|}{ Description: } & Ose Coffee & HS Coffee \\
\hline 1. & Production Value (IDR) & $4.625,00$ & $6.018,75$ \\
\hline 2. & Intermediate Cost (IDR) & $4.095,88$ & $5.044,04$ \\
\hline 3. & Added Value (IDR) & 529,11 & 974,71 \\
\hline 4. & Added Value Ratio (\%) & 11,44 & 16,19 \\
\hline 5. & Profit Ratio (\%) & 5,52 & 15,96 \\
\hline
\end{tabular}

The Table 1 showed that the average value added per kilogram of raw material to the preparation of dry ose coffee at Desa Sidomulyo of IDR 529.11. It indicated that the average farmer acceptance of each kilogram of dried gelondong coffee is processed into dried ose coffee of IDR 529.11. This added value was the remuneration of the factors that did the management of gelondong coffee process the activities became dry ose coffee. Value added was the difference between the value of the intermediate production cost, while the value added ratio was value added divided by the value of production multiplied by $100 \%$. The added value obtained by farmers benefit after deducting the labour cost. The value of profits was IDR 255.371 profits. Ratio amounted to $5.52 \%$, which means that every 100 units produced ose coffee production would be obtained profit as much as 5.52 units. Profit value was the difference between value added by labor costs, while the ratio of profit was profit divided by the value of production multiplied by $100 \%$. Ratio of value added by $11.44 \%$, while the ratio gain of $5.52 \%$. It showedthat the ratio of value added was greater than the profits ratio which means that farmers were more concerned with the allocation of income from management factors, which form of value added compared to wage labour. The results of above research showed that the process the of gelondong coffee into dry ose coffee loop would get additional production of higher value compared for selling coffee without being processed.

Adding value of HS coffee if higher wet coffee when compared with unprocessed red spools. The added value also can be described through material processing that causes the value production. The production value is a multiplication between the selling prices of a product by a conversion factor. In the wet processing of coffee into HS coffee for wet processing, there is shrinkage about 0.2 to 0.3 . HS Coffee has units of litres, so that to get the value added per $\mathrm{kg}$ of raw material processed coffee on HS coffee powder must be converted to units of kilograms. Conversion factor between litres and kilograms is 0.75 , which means that one litre is as same as 0.75 kilograms.

The added value was the difference between cost production and intermediate cost. Intermediate cost value was the value of total value other than labour costs divided by the number of raw materials used. Total costs included variable costs and fixed costs. Variable costs on a wet gelondong coffee processing coffee HS became the raw material costs, packaging costs, labour costs, and transportation costs. While the cost of equipment used in the processing is the cost of processing services. In the wet processing of coffee into coffee HS, the farmers were charged to the agro-industry processing services at a price of IDR 500.00 per kilogram. That was because the farmers did not have coffee into coffee processing tool HS, so that farmers brought coffee to the agro-industry to be processed. In the analysis of value added in the wet coffee processing into HS coffee used per data production process.

The Table 1 showed that the average value added per kilogram of raw material in processed coffee into coffee if wet in the Village HS Sidomulyo of IDR 974.71. This indicated that the average revenue from each kilogram of gelondong coffee farmers was processed into wet HS coffee IDR 974.71. The value of added was the difference between the value of production with intermediate cost, while the ratio of the value added was divided by the value of production multiplied by 100 percent. The added value of the average was obtained by farmers benefit after deducting the cost of labour. The value of profits is IDR 960.39, while the profits ratio amounted to $15.96 \%$, meaning that for every 100 units of coffee production if wet HS produced as much benefit will be obtained 15.96 units. The value of profit was the difference between value added by labour costs, while the profit ratio was profit divided by the value of production 
multiplied by 100 percent. Ratio of $16: 19 \%$ value added, while the ratio of a gain of $15.96 \%$. This showedthat the value added ratio was higher than the profits ratio which means that the average income of farmers concerned with the allocation of the factors management. The results of these studies indicated that the wet coffee process the into HS coffee if wet would get additional production of higher value compared for selling wet coffee without being processed.

\section{B. Incentives and Sports Wet Method}

Wet processing activities on rice coffee products was done in the Village District of Silo Sidomulyo Jember which was one rice coffee processing effort on the part surrounding communities with the goal to improve the lives of coffee farmers, expand employment opportunities and improve the quality of coffee in the Village District of Silo Sidomulyo Jember. Wet processing was done at the coffee Sidumulyo Village that is the second largest coffee producing village in the District of Shiloh. The wet processing activities carried out with the aim of improving the standard of coffee farmers, therefore, need to know the factors driving and inhibiting factors in the wet processing of coffee products Sidomulyo rice in the village.

The value of TNB biggest driving factors is labor absorbing with a value of 1.46. Absorb labor in the wet processing of coffee products in the village Sidomulyo rice is a major factor, due to the presence of the wet processing of coffee rice absorbs it more and more manpower. Rice soaked in coffee processing was done in the factory, where the owner of the factory land was owned by one of the farmers and also the coordinator in the wet processing of coffee in the village rice Sidomulyo District of Silo. In the wet processing plant there are various kinds of activities each wet processing and a series of activities in the wet processing plant requires labour, especially those who are experts and can operate the tools contained in the plant. By absorbing the labour force will help the community's economy by providing jobs contained in the plant. With the good labour in factories it will affect the quality of the coffee. Rice coffee in the wet processing also will run faster and more efficiently. The selling price of rice coffee is also a driving factors because if the wet coffee sales price is more expensive than the selling price if dried coffee. Copies of the results of the wet processing of export quality coffee. Supported by the natural resources in the village Sidomulyo was very supportive both in farming and in the wet processing of coffee in rice coffee. The factors of key success of limiting factor on wet processing of coffee products in the village rice Sidomulyo are shown in the Table 2 .

Based on the Table 2, the factors of key success were known that the limiting factor in the wet processing of coffee products Sidomulyo rice in the village was the lack of adequate water facility with BNP value of 1.17 . Inadequate water supply system in the village had resulted Sidomulyo wet processing was done in the factory became blocked, resulting in inefficient processing activity mainly at coffee washing process became ineffective and the impact on coffee quality was not good. Inadequate water supply system caused by dam water contained in the water source in the village said Sidomulyo still not adequate, because until now the water dam was made of sacks containing sand so that water was pervasive and difficult to flow into waterways aimed to society. It was very influential in the interest of farmers to do wet processing. The equipment used was also very limited influence on the processing of coffee rice. The lack of knowledge about how wet processing also affect the interest of farmers in the do wet processing. Unpredictable weather was a limiting factor because it affects the process of coffee, especially in the drying process that requires the help of sunlight. Coffee waste disposal was still not under control and causing environmental pollution around the plant. Fluctuating coffee prices was also a limiting factor because the price of coffee every year and affect the change on a wet processed coffee.

TABLE II

ForCe Field ANALysis Method of Wet Processing of the CofFEE

\begin{tabular}{|c|l|c|c|}
\hline No & \multicolumn{1}{|c|}{ Supporting factors } & TNB & FKK \\
\hline D1 & Quality coffee exports & 1.18 & \\
\hline D2 & Faster processing & 0,63 & \\
\hline D3 & Natural resources that support & 0,58 & \\
\hline D4 & $\begin{array}{l}\text { Sewage can be used as organic } \\
\text { fertilizer }\end{array}$ & 0,63 & \\
\hline D5 & $\begin{array}{l}\text { The selling price of coffee is more } \\
\text { expensive }\end{array}$ & 0,71 & \\
\hline D6 & Absorbed more labor & 1,46 & $*$ \\
\hline & \multicolumn{1}{|c|}{ Inhibiting factors } & TNB & FKK \\
\hline H1 & The equipment used is still limited & 0,99 & \\
\hline H2 & The lack of knowledge of farmers & 0,63 & \\
\hline H3 & Inadequate water facilities & 1,17 & $*$ \\
\hline H4 & Unpredictable weather & 0,67 & \\
\hline H5 & $\begin{array}{l}\text { Waiting time picking coffee quite a } \\
\text { long }\end{array}$ & 1,15 & \\
\hline H6 & Capital that still lack sufficient & 0,78 & \\
\hline
\end{tabular}

$\begin{array}{ll}\text { Description: } \\ \text { BF } & \text { : Weight of factors } \\ \text { ND } & : \text { The value of Support } \\ \text { NRK } & \text { : Average Value Linkage } \\ \text { NBD } & : \text { Weight of The Support value } \\ \text { NBK } & : \text { Weight of The Linkage value } \\ \text { TNB } & : \text { Total The value of Weight } \\ \text { FKK } & : \text { Key Success Factors }\end{array}$

The direction Expected

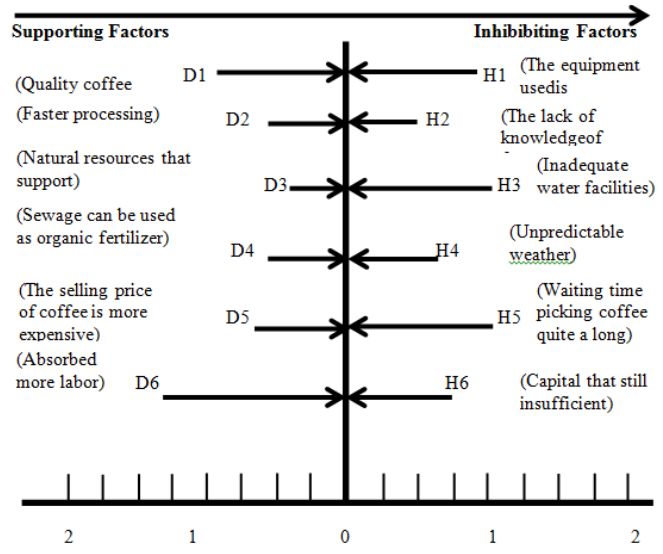

Fig. 1 Wet Processing Diagram Force Field At Rice Coffee In Sidomulyo Village District of Silo 
Based on the Image 1, visualization and inhibiting driving factors force farmers to process soaked in rice coffee Sidomulyo in the village. The value of driving factors and inhibiting force farmers to wet processing is indicated by the value of the total value of weight (TNB) are shown in the Table evaluation driving factors and inhibitor farmers in making the coffee wet processing of rice in the village Sidomulyo. Based on the value of BNP in the second table above, it is known that the value of BNP for the driving factor is 1.46 and the value of BNP for inhibiting factor is 1.17 .

\section{Coffee farming income}

Acquisition of coffee farming was obtained from the total revenue minus the costs incurred during the production process. Total revenue was derived from production multiplied by the price of rice coffee. The amount of the selling price of coffee was wet processed by IDR 16250.00 per $\mathrm{kg}$ and for the price of dry processed coffee is IDR 13000.00 per $\mathrm{Kg}$. The total cost incurred farmers from various elements of which variable costs and fixed costs. Variable costs consist of the cost of fertilizer, the cost of medicines, labour costs and other costs. Fixed costs consist of the cost of property taxes.

The cost of fertilizer was obtained from the sum of the costs of each type of fertilizer used by farmers. Fertilizers used by farmers such as urea, Za, Ponska, and organic fertilizer. Farmers also some use additional fertilizer which fertilizer and Petroganik rainbow. Fertilizer application was generally done twice in one year, performed at the beginning and at the end of the rain. Effect of nitrogen fertilizer, Za and ponska a ratio of 2: 1: 1 for each additional tree and organic fertilizers such as manure, rainbow and Petroganik used for stimulating the growth of the plants and fruit.

The cost of drugs derived from the sum of the cost of each type of drug. Drugs that were used by farmers were generally purchased at kiosks or at the farm shop. Types of drugs used by farmers varied and differ from one farmer to another farmer. At the coffee plant was very rarely attacked by pests or diseases that were very disturbing plants so that farmers rarely use drugs. Pests or diseases of plants were often found in coffee plants were stem borer. Farmers eradicate these pests simply by cutting the stems were broken. There were also farmers who use drugs like bulldog to eradicate the ant, Gramakson eliminate weeds, Bayu, and Herbicides.

The cost of labour was obtained from the sum of the wages of each unit of work that went into the work day, a day where there were 8 hours of work. Activities undertaken include labor fertilization and weeding, pruning, pest and disease control, and harvesting and post-harvest. The cost of each activity generally IDR 20,000 per man our / HOK. Working hours for labour is different, but generally starts from 07:00 until 15:00.

Fixed costs included the cost of property taxes charged to farmers. The cost of property taxes each farmer was different depending on the area of land that they have. The average cost per hectare property taxes of IDR 20,000.00 Average wet though coffee production in 2010 in the village of Shiloh Sidomulyo the District of $1176.41 \mathrm{~kg} / \mathrm{ha}$, whereas if dried coffee production of $1162.22 \mathrm{~kg} / \mathrm{ha}$. Based on the results obtained for the calculation of average revenues, expenses and income per hectare for coffee farming was done wet processing and dry processing in 2010 is shown in Table 3.

TABLE III

Average Revenue, Cost and Revenue Per Hectare Farm Coffee

\begin{tabular}{|c|c|c|c|}
\hline Processing type & $\begin{array}{c}\text { Acceptance } \\
\text { (IDR/Ha) }\end{array}$ & $\begin{array}{c}\text { Cost } \\
\text { (IDR/Ha) }\end{array}$ & $\begin{array}{c}\text { Revenue } \\
\text { (IDR/Ha) }\end{array}$ \\
\hline Wet Processing & $18.360 .000,00$ & $7.131 .194,87$ & $11.228 .805,13$ \\
\hline Dry Processing & $14.310 .553,85$ & $6.341 .740,23$ & $7.901 .249,51$ \\
\hline
\end{tabular}

Based on the Table 5.8, the average income per hectare coffee farm in the village of the District Sidomulyo Silo in 2010 for having coffee wet processing of IDR. $11,228,805.13$ per acre and for dry processing of coffee done by IDR. 7,901,249.51 per hectare. It means that the income of coffee farmers who did wet processing (IDR. $11,228,805.13$ per hectare) was higher than the incomes of farmers who did dry processing (IDR. 7,901,249.51 per hectare). The income of coffee farmers who did wet processing was greater than the incomes of farmers who did dry processing because in terms of the average wet processed coffee production was greater than the average production of dry processed coffee. In addition, in terms of the average selling price per hectare of wet coffee higher than the average sales price per hectare of dry coffee. For the price of coffee is wet while the selling price of IDR 16,250 IDR dried coffee 13,000.

The income received by farmers was the result of a reduction between total revenue and total costs. Total revenue was the result of multiplying the price by the number of products. The total cost was the sum of the fixed costs to variable costs. Acceptance among farmers who did wet processing of coffee and coffee farmers who did dry processing could be seen from the price and the amount of product produced. If wet coffee price was IDR. $16250.00 \mathrm{Kg}$ per ha and dry coffee was IDR.13000.00 Kg per Ha. Total costs were the costs incurred for farming. The total cost of the coffee farm was the sum of fixed costs and variable costs. Fixed costs were property taxes (UN), while the variable costs include the cost of fertilizers, pharmaceuticals, labour and other costs. The average total cost of the coffee farming if wet is IDR. 7,131,194.87 per ha and the average total cost at the farm if dried coffee was IDR 6,341,740.23 per Ha.

Coffee farm income derived from the difference between total revenue to total cost incurred in the production period. Acceptance in coffee farming is the product of the number of production and selling price. Incomes per hectare coffee farm IDR if wet. $11,228,805.13$ and the value was greater than the dry coffee farm income of IDR. 7,901,249.51

\section{CONCLUSIONS}

Based on the analysis and discussion that had been done, the conclusions are as follows: Processing coffee divided into two wet processing and dry processing. Some farmers for $75 \%$ did dry processing with the highest reason was easy in the treatment process, while $25 \%$ farmers did wet processing with the highest reason was the price of coffee is 
more expensive. The factors that significantly affect the decision making coffee farmers who did wet processing Sidomulyo Village is aged farmers and profits, while the factor of experience, education, land area, number of family members and the total cost of harvesting and post-harvesting effect was not real. Wet processing of the strongest support factor was the ability to absorb labour, while the strongest inhibitor factor is the lack of adequate wet processing water facilities. The income coffee farmers wet processing and dry processing was different. Revenue per ha coffee wet processing of IDR. 11,228,805.13 and coffee income per ha of dry processing of IDR. 7,901,249.51.

\section{ACKNOWLEDGMENT}

Thank submitted to the Directorate of Research and Community Services, which has provided research funding through the Strategies National Research Scheme on 20122014.

\section{REFERENCES}

[1] Badan Pusat Statistik Kabupaten Jember. 2011. Kabupaten Jember dalam angka. Jember: Badan Pusat Statistik Kabupaten Jember

[2] Central Bureau of Statistics of Jember, In 2011. Jember Distric in Numbers. Jember:

[3] Buffa. 1994. Production Management/ Modern Operation. Jakarta : Binarupa Aksara.

[4] Dinas Perkebunan Pemerintahan Provinsi Jawa Timur. 2011. Plantation Development. [on line]. http://disbunjatim.go.id/ arealtanaman.php. Accessible on 17th September 2012.
[5] Kotler, P. 2000. Marketing Management. Jakarta : Prenhallindo.

[6] Masyhuri. 2008. Metodologi Penelitian Pendekatan Praktis dan Aplikatif. Bandung: Refika Aditama.

[7] Najiyati dan Danarti. 2004. Coffee: Cultivation and Post Harvest Handling. Jakarta: Penebar Swadaya.

[8] Nasution, R. 2003. Sampling Methods: Fakultas Kesehatan Masyarakat Universitas Sumatera Utara. [serial online]. Library.usu.ac.id/download/fkm/fkm-rozaini.pdf.[5 Oktober 2012]

[9] Nazir. 2009. Research Methods. Bandung: Ghalia Indonesia.

[10] Porter. 1993. Competitive Advantages: Creating and Sustraining Supervisor Performances. New York: The Free Press Msc Millan Inc.

[11] Setiadi, Nugroho. 2008. Business Economics and Managerial Decision Making: Aplikasi Teori Ekonomi dan Pengambilan Keputusan Manajerial dalam Dunia Bisnis. Jakarta: Kencana.

[12] Soeharjo, A. 1997. Farming Systems Development. Bogor: Laboratorium Ekonomi dan Manajemen Agribisnis Institut Pertanian Bogor.

[13] Soekartawi. 1991. Agribusiness Theory and Application. Jakarta: PT. Raja Grafindo Persada.

[14] Yahmadi, Mudrig. 2007. The series of developments and issues Cultivation \& Processing Coffee in Indonesia. Surabaya: AEKI

[15] Ghozali, Imam. 2009. Advanced Multivariate Analysis with SPSS. Semarang: Badan Penerbit Universitas Diponegoro.

[16] Najiyati dan Danarti. 2009. Coffee (Cultivation and Harvest Handling).Jakarta: Penebar Swadaya.

[17] Nazir, Mohammad. 1988. Research Methods. Jakarta: Ghalia Indonesia.

[18] Pujiyanti. 1998. Perkebunan besar sebagai penyangga kelestarian alam. Dalam warta pusat penelitian kopi dan kakao. Jember: pusat penelitian kopi dan kakao. Asosiasi Penelitian Perkebunan Indonesia.

[19] Suhartana, Nana dan Sumino. Tanpa Tahun. Menuju Pemasaran Kopi Spesial. http://www.scribd.com/doc/32601267/Rantai-DistribusiPemasaran-Kopi-Di-4-Sentra-Kopi-di-Indonesia.index.html. 